\title{
Effect of Straw Substrates and Casing Materials on Yield of Milky Mushroom (Calocybe indica P\&C.) Strain CI-524
}

\author{
Anurag Kerketta*, Nand Kishore Pandey, H.K. Singh and C.S. Shukla \\ Department of Plant Pathology, College of Agriculture, Indira Gandhi Krishi \\ Vishwavidyalaya, Raipur- 492012, Chhattisgarh, India \\ *Corresponding author
}

\begin{abstract}
A B S T R A C T
Keywords

Milky mushroom,

Straw substrates,

Casing materials,

Biological efficiency and CI

Article Info

Accepted:

04 January 2018

Available Online:

10 February 2018

Present experiment was carried out in Mushroom Research Laboratory, Department of Plant Pathology, IGKV, Raipur during 2015-16 to know the effect of alone and combination of different growing straw substrates and casing materials in yield of Calocybe indica. The combination of wheat + Lathyrus straw gave significantly maximum yield (765g) with BE $(76.5 \%)$ followed by alone wheat straw $(696.67 \mathrm{~g})$ with $\mathrm{BE}(69.66 \%)$, whereas the minimum fresh yield (390g) with $\mathrm{BE}(39 \%)$ was obtained from the combination of wheat + mustard straw. The fresh yield of strain CI-524 of C. indica differed significantly with different casing materials. Compost + Vermicompost gave significantly higher yield (813.33g) with BE $(81.33 \%)$ followed by vermicompost (748.33g) with $\mathrm{BE}(74.83 \%)$ and compost [Garden soil + FYM (1:1)] gave minimum yield (690g) with BE (69.0\%).
\end{abstract}

\section{Introduction}

A substrate is an important substance for growing mushrooms. Usually, a wide range of diverse cellulosic substrates are used for cultivating mushrooms. Various agricultural byproducts are being used as substrates for the cultivation of oyster mushrooms, including banana leaves, peanut hull, corn leaves, mango fruits and seeds, sugarcane leaves, and wheat and rice straw (Cangy et al., 1995). In Asia, rice straw is widely used as the substrate for cultivating oyster mushroom. A lot of biowaste is being generated in rural areas and this can be utilized directly through mushroom cultivation. The cultivation of mushroom is unique in the sense that it is the most efficient and economically viable biotechnological process for the conversion of lignocellulosic waste material into high quality protein rich palatable food. Nowadays, there is a need to promote the cultivation of mushroom to meet the challenges of increasing world population as well as energy crisis.

Production of food in a cheaper and simpler way carries more significance in developing countries like India. Considering the growth 
requirements, milky mushroom fits very well to this situation (Jadhav et al., 2014).

Calocybe indica, a popular mushroom was first time reported from India in 1976 (Purkayastha and Chandra, 1976). It can be easily gown in the temperature range of 25 to $35^{\circ} \mathrm{C}$ with 75 to $85 \%$ relative humidity. It has a good biological efficiency (60 to $70 \%$ ) under optimal growth conditions. Its robust size, sustainable yield, attractive color, delicacy, long shelf-life, and lucrative market value have attracted the attention of both mushroom consumers and prospective growers (Chakraborty and Sikdar, 2010). C. indica is rich in protein, lipids, fiber, carbohydrates, and vitamins and contains an abundant amount of essential amino acids (Alam et al., 2008). Large quantities of lignocellulosic residues such as rice straw, wheat straw, mustard straw, maize straw, waste cotton, pigeon pea and sugarcane bagasse are generated annually through activities of the agricultural, forest, and food processing industries in India. This can be used for mushroom production. Thus present investigation was undertaken to determine the suitable combination of substrate and casing materials for production of milky mushroom.

\section{Materials and Methods}

\section{Mushroom strain and substrates}

Calocybe indica strain CI-524 was obtained from All India Co-ordinated Research Project on Mushroom, Department of Plant Pathology, College of Agriculture, IGKV, Raipur. Different types of straw substrates alone and in combination [wheat, wheat + lathyrus, wheat + mustard, wheat + pigeon pea and wheat + maize $(1: 1)$ ] were used to see the effect in yield of $C$. indica. Substrates were collected from nearby village. The observation was recorded for spawn run pin head initiation and yield of $C$. indica.

\section{Preparation of mushroom bag}

The various straws (chopped) were used as substrate for growing of $C$. indica. The substrate was dipped in water (which has already mixed with $75 \mathrm{ppm}$ Carbendazim and $500 \mathrm{ppm}$ formaldehyde) for 14 hours as per the method described by Vijay and Sohi (1987).

Thereafter, excess water was drained off the next morning and straw was spread over on sloppy, cemented floor till the moisture content of straw remained 65-70 per cent. Before spawning, formaldehyde was sprinkled on floor, and thereafter the spawn was mixed in substrate through layering method @ 4 per cent on wet weight basis in all experiments. The spawned substrate was filled in poly propylene bags $(18 " \times 27 "-150$ gauges $)$ and mouth of the spawned bag was tied with nylon rope. The spawned bags were kept in mushroom growing room, where appropriate temperature $\left(25-35^{\circ} \mathrm{C}\right)$ and relative humidity (80-90 per cent) were maintained by frequently sprinkling of water on walls and floor. After complete colonization of substrate by mushroom mycelium (spawn run), casing were done.

\section{Casing materials}

Various types of casing materials viz., compost \{garden soil + FYM (1:1)\}, vermicompost and combination of compost + vermicompost $(1: 1)$ were used to casing the bag and observation was noticed for spawn run, pin head initiation and yield of $C$. indica.

\section{Yield and biological efficiency}

Total weight of all the fruiting bodies harvested from all the three pickings were measured as total yield of mushroom. The bioefficiency (yield of mushroom per $\mathrm{kg}$ substrate on dry wt. basis) was calculated by the following formula (Chang et al., 1981). 
Fresh weight of mushroom Biological efficiency $\%=$

Dry weight of substrate

\section{Statistical analysis}

The experiment was laid out in a completely randomized design with three replications. The following data were collected; the number of days required for the spawn run, the days required for initiation of pinhead, biological yield, and biological efficiency. The critical difference (C.D.) was calculated at 5\% levels.

\section{Results and Discussion}

\section{Effect of different straw substrates on yield of strain CI-524 of $C$. indica}

To find out the suitable substrate for growth and yield of $C$. indica, wheat and four substrates combined with wheat straw were evaluated. The results are presented in Table 1 .

The time required for spawn run by strain $C$. indica varied significantly with respect to different substrate used. Spawn run was earlier in alone wheat and wheat + pigeon pea $(12$ days) followed by three combination wheat + lathyrus, wheat + mustard and wheat + maize (13 days). The time taken for pin head initiation differed significantly with respect to different substrates. Pin head initiation was quicker in alone wheat straw (7 days) followed by wheat + mustard (10 days), two combination wheat + lathyrus and wheat + pigeon pea (11 days). However, spawn run period was significantly delayed in combination wheat + maize (12 days). The fresh yield of $C$. indica also differed significantly with respect to different substrates. The combination of wheat + lathyrus straw gave significantly maximum yield $(765 \mathrm{~g})$ with $\mathrm{BE}(76.5 \%)$ followed by alone wheat straw $(696.67 \mathrm{~g})$ with $\mathrm{BE}$ $(69.66 \%)$, wheat + maize $(435 \mathrm{~g})$ with $\mathrm{BE}$
(43.50\%) and the combination of wheat + pigeon pea straw $(405 \mathrm{~g})$ with BE $(40.50 \%)$ whereas, the minimum fresh yield $(390 \mathrm{~g})$ with BE (39\%) was obtained from the combination of wheat + mustard straw.

Tandon and Sharma (2006) evaluated four different substrates and three supplements for the sporophore yield of $C$. indica. WS proved to be best substrate giving $520 \mathrm{~g}$ yield per $3 \mathrm{~kg}$ wet substrate.

Mane et al., (2007) studied the several agro wastes viz. cotton stalks, groundnut haulms, soybean straw, pigeon pea stalks and leaves and wheat straw alone or in combinations for cultivation of $P$. sajor-caju. Bhatt et al., (2007) showed that among the tested substrates for cultivation of $C$. indica, wheat straw took minimum period for spawn run (14 days) which was at par with wheat straw + paddy straw $(2: 1)$ but significantly lesser than the period taken by other substrate.

\section{Effect of different casing materials on yield of strain CI-524 of $C$. indica}

Various casing materials were studied on spawn run, pinhead initiation and yield of strain CI-524 of $C$. indica. The results obtained are given in Table 2.

Different casing materials did not show any significant difference with each other in spawn run and pin head initiation. It varied from 1112 days for spawn run. The pinhead initiation was from 10-11 days. The fresh yield of strain CI-524 of $C$. indica differed significantly with different casing materials. Compost + Vermicompost gave significantly higher yield $(813.33 \mathrm{~g})$ with BE $(81.33 \%)$ followed by vermicompost $(748.33 \mathrm{~g})$ with $\mathrm{BE}(74.83 \%)$ and compost [Garden soil + FYM (1:1)] gave minimum yield (690g) with BE (69.0\%). (Kale, 1998; Nagaratna and Mallesha, 2007) (Fig. 1 and 2). 
Table.1 Effect of different straw substrates on yield of Calocybe indica

\begin{tabular}{|l|l|c|c|c|c|c|}
\hline S. No. & Treatments & $\begin{array}{c}\text { Yield (g)/ kg dry straw substrate } \\
\text { Run (Days)* }\end{array}$ & $\begin{array}{c}\text { Pinhead Initiation } \\
\text { (Days)* }\end{array}$ & Yield (g)* & BE (\%) \\
\hline $\mathbf{1}$ & Wheat & 12 & 7 & 696.67 & 69.66 \\
\hline $\mathbf{2}$ & Wheat + Lathyrus (1:1) & 13 & 11 & 765.00 & 76.50 \\
\hline $\mathbf{3}$ & Wheat + Mustard (1:1) & 13 & 10 & 390.00 & 39.00 \\
\hline $\mathbf{4}$ & Wheat + Pigeon pea (1:1) & 12 & 11 & 405.00 & 40.50 \\
\hline $\mathbf{5}$ & Wheat + Maize (1:1) & 13 & 12 & 435.00 & 43.50 \\
\hline
\end{tabular}

Table.2 Effect of different casing materials on yield of Calocybe indica

\begin{tabular}{|c|c|c|c|c|c|}
\hline \multicolumn{6}{|c|}{ Yield (g)/ kg dry wheat substrate } \\
\hline S. No. & Treatment & Spawn Run & Pin head Initiation & Yield $(g)^{*}$ & BE $(\%)$ \\
\hline & & $($ Days)* & $(\text { Days })^{*}$ & & \\
\hline 1 & $\begin{array}{l}\text { Compost } \\
{[\text { Garden soil + FYM (1:1) ] }}\end{array}$ & 12 & 11 & 690.00 & 69.00 \\
\hline 2 & Vermicompost & 12 & 11 & 748.33 & 74.83 \\
\hline \multirow[t]{3}{*}{3} & Compost + Vermicompost $(1: 1)$ & 11 & 10 & 813.33 & 81.33 \\
\hline & SEm \pm & 0.43 & 1.13 & 19.41 & \\
\hline & $\operatorname{CD}(5 \%)$ & NS & NS & 67.17 & \\
\hline
\end{tabular}

(*) - Average of three replication.

(NS) - Non Significant. 
Fig.1 Effect of different substrates on yield and BE of Calocybe indica

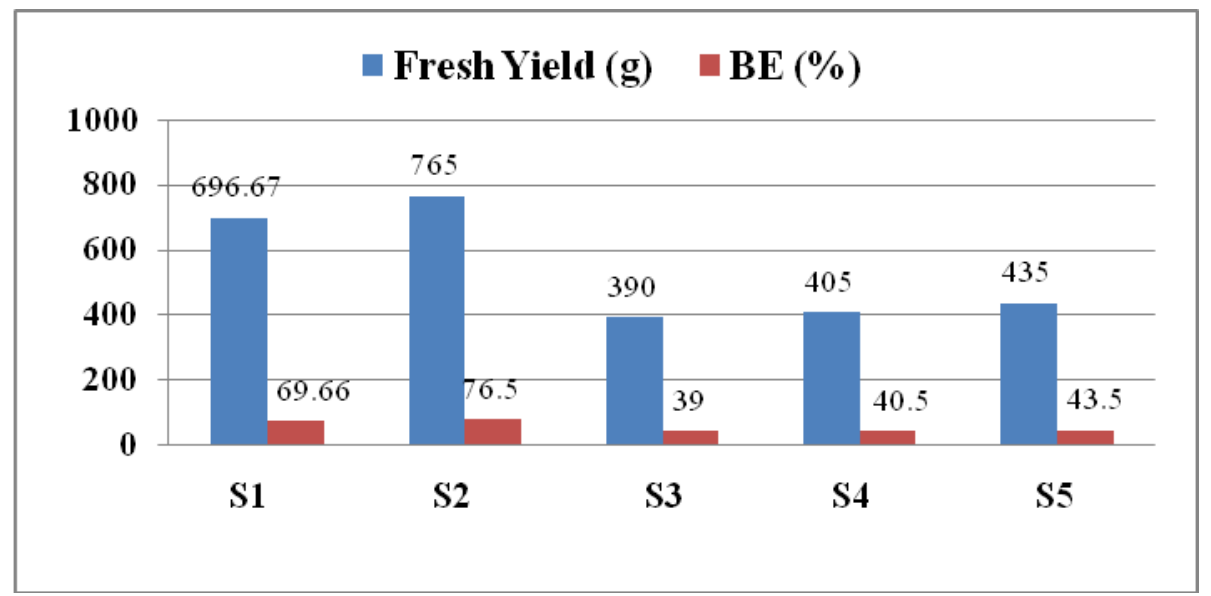

(Key: S1-wheat, S2-wheat+lathyrus, S3-wheat+mustard, S4-wheat+pigeon pea, \& S5-wheat+maize.)

Fig.2 Effect of different casing materials on yield and BE of Calocybe indica

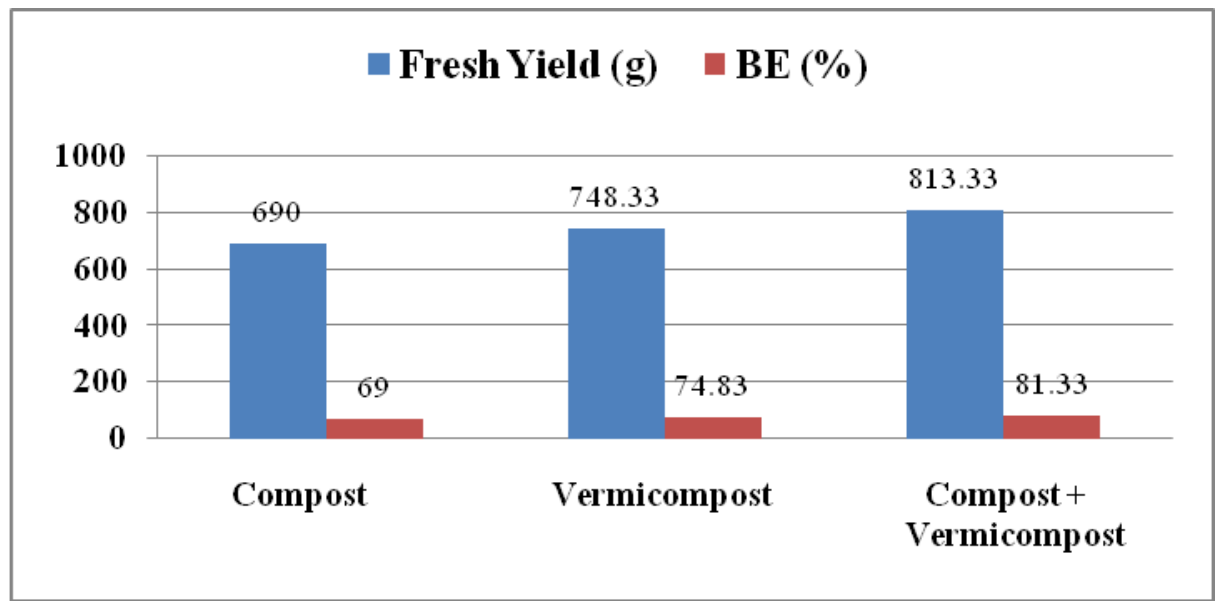

Reported that the vermicompost as the casing medium recorded for the high bioefficiency $(111.98 \%)$ of $C$. indica. (Hayes, 1995; Colak, 2004) The combination of composted cow dung and loamy soil proved to be a good casing material, which likely played a role in stimulating the initiation of the fruiting body.

Straw substrate and casing material is an important substance for cultivation of milky mushroom.

Based on present investigation it can be concluded that among the tested straw substrates, wheat straw with addition of lathyrus straw best for milky mushroom cultivation which gave maximum yield. Similarly combination of compost + vermicompost as a casing material found to be best for maximum yield of milky mushroom.

\section{Acknowledgement}

First author is heartily thankful to all the staff members of Mushroom division, Department of Plant Pathology, College of Agriculture, IGKV, Raipur, Chhattisgarh for their help, guidance and encouragement during the period of investigation. 


\section{References}

Alam, N., Amin, R., Khan, A., Ara, I., Shim, M.J., Lee, M.W., Lee, T.S. 2008. Nutritional analysis of cultivated mushrooms in Bangladesh: Pleurotus ostreatus, Pleurotus sajor-caju, Pleurotus florida and Calocybe indica. Mycobiology 36: 228-32.

Bhatt, P., Kushwaha, K.P.S. and Singh, R.P. 2007. Evaluation of different substrates and casing mixtures for production of Calocybe indica. Indian Phytopath. 60: 128-130.

Cangy C, Peerally A. 1995. Studies of Pleurotus production on sugarcane bagasse. Afr J Mycol Biotechnol. 3: 6779.

Chakraborty U, Sikdar SR. 2010. Intergeneric protoplast fusion between Calocybe indica (milky mushroom) and Pleurotus florida aids in the qualitative and quantitative improvement of sporophore of the milky mushroom. World J Microbiol Biotechnol. 26: 213-25.

Chang, S. T., Lau, O. W. and Cho, K. Y. 1981. The cultivation and nutritive value of Pleurotus sajor - caju. European J. Appl. Microbiol. Biotechnol. 12: 58-62.

Colak M. 2004. Temperature profiles of Agaricus bisporus in composting stages and effects of different composts formulas and casing materials on yield.
Afr J Biotechnol. 3: 456-62.

Hayes WA. 1985. Interaction between compost and casing soil substrates in the culture of Agaricus bisporus. Mush J. 151:281-285.

Jadhav, A. C., Shinde, D. B., Nadre, S. B and Deore, D. S. 2014. Quality improvement of casing material and yield in milky mushroom (Calocybe indica) by using biofertilizers and different substrates. Proceedings of the 8th International Conference on Mushroom Biology and Mushroom Products. pp. 359-364.

Kale, D. R. 1998. Earthworm Cinderella of Organic Farming, Prism Books private Limited, Bangalore. pp. 65-69.

Nagaratna, G. K., and Mallesha. B. C. 2007. Use of Vermicompost as casing material for cultivation of milky mushroom. Mushroom Research. 16: $81-83$

Purkayastha, R.P. and Chandra, A. 1976. A new technique for in vitro production of Calocybe indica-an edible mushroom of India. Mush J. 40: 112-113.

Tandon, G. and Sharma, V.P. 2006. Yield performance of Calocybe indica on various substrates and supplements. Mush. Res. 15: 33-35.

Vijay, B. and Sohi, H. S. 1987. Cultivation of oyster mushroom Pleurotus sajor-caju (Fr.). Singer on chemically sterilized wheat straw. Mush. J. Tropics 7: 67-75.

\section{How to cite this article:}

Anurag Kerketta, Nand Kishore Pandey, H.K. Singh and Shukla, C.S. 2018. Effect of Straw Substrates and Casing Materials on Yield of Milky Mushroom (Calocybe indica P\&C.) Strain CI-524. Int.J.Curr.Microbiol.App.Sci. 7(02): 317-322. doi: https://doi.org/10.20546/ijcmas.2018.702.041 